\title{
An Approach for Building a CGE Database for the North Korean Economy*
}

\author{
Inkyo Cheong
}

\begin{abstract}
Since it is difficult for researchers to access data for the North Korean economy, they typically choose a proxy economy for estimating the economic impact of the unification of the two Koreas using a computational general equilibrium (CGE). This paper aims to identify the best proxy economy for North Korea out of the 140 economies (countries) in the Global Trade Analysis Project (GTAP) database version 9.1, which was published in mid-2015. (Ed-if your study aim is 'to identify the best proxy economy for North Korea', then you must state your study finding here in the abstract, and also in the conclusion, i.e., Romania) This paper evaluates the input-output (IO) tables for the North Korean economy in existing studies. Comparing the coefficients for North Korea in existing studies with those of the countries selected for this paper, substantial differences were found, especially for the services sector. This casts some doubt on the IO tables in the existing studies on the North Korean economy.
\end{abstract}

Keywords: Unification, input-output (IO) tables, North Korean economy, computational general equilibrium (CGE)

JEL codes: P33, C67, D57

Submission Date: 27/02/2016 Revision Date: 16/04/2016 Acceptance Date: 25/04/2016

* This paper was financially supported by the Jungseok Research Institute for International Logistics and Trade (JRI) with the research title of "Building a CGE Model for Economic Integration in Korea" in the 2015 academic year. The author appreciates JRI's support, although any remaining errors are the author's. 


\section{Introduction}

For several decades, discussion on and research into the unification of the two Koreas have focused on the costs rather than the benefits. However, after Goldman Sachs published a report on the benefits of Korean unification in 2009, Korea's national think tanks began to explore its positive aspects. One of these research reports by a think tank is Korea Institute of International Economic Policy (KIEP, 2014). Estimating the economic impact of Korean unification requires a relevant economic model of the North Korean economy. KIEP used the Global Trade Analysis Project (GTAP) model and its database of 129 countries (version 8.1), and chose Tanzania as a proxy economy for North Korea, since its economic size is closest to that of North Korea. Despite the very limited economic data for the North Korean economy, the suspicion remains that there might be better proxy economies than Tanzania, which is located in Africa.

The purpose of this paper is to identify the best proxy economy for North Korea out of the 140 economies (countries) in the GTAP database version 9.1, which was published in mid-2015. Doubt may be raised regarding whether researchers can build a computational general equilibrium (CGE) database for the North Korean economy with the currently available information. Building such a database is a necessary, but almost impossible, task. Unless researchers fully understand the whole structure of an economy in the context of the economic linkages among the major economic agents, it is not possible to develop an Input-Output (IO) and general equilibrium-type database. 1) Section 2 of this paper discusses the extent of necessary information for a CGE database.

Despite the limited spread of a market economy, North Korea has maintained a centrally planned economic system for more than half a century. Since most former socialist countries have transformed into market economic systems, there remains no planned economy with an economic scale similar to that of North Korea. Nevertheless, it may be possible to identify a better proxy country than Tanzania, as used in KIEP (2014). As KIEP (2014) states, the similarity in economic scale can be a decision factor for choosing a proxy economy, but the similarity of the IO structure, especially the Leontief-inverse matrix, may be more critical, considering the characteristics of CGE analysis. Moreover, former socialist countries may be better candidates than original market economies, when taking the current economic system of the North Korea into consideration.

1) A few papers have examined the North Korean economy with CGE models, but they incorporated only a part of the economic data for North Korea. 
Because of the limited data available, this paper does not try to build a CGE model for the North Korean economy, but rather attempts to discuss how to choose a proxy economy out of the 140 economies in GTAP. This paper evaluates the IO tables for the North Korean economy in existing studies. Comparing the coefficients for North Korea in existing studies with those of the countries selected for this paper, substantial differences were found, especially for the services sector. This may cast some doubt on the IO tables in the existing studies on the North Korean economy.

\section{A database for a CGE model}

\subsection{Existing studies}

The many approaches (i.e., economic models) that have been taken to estimate the impacts of policy changes can be grouped into partial and general equilibrium analyses. While there has been a boom in research into Korean unification, relatively few studies have been conducted on its impact, when considering the extent of national concern over the issue. No consensus has been reached as to how to measure the impact of economic integration, which is a part of national unification. ${ }^{2)}$

Researchers can estimate the impacts of national unification using several approaches, ranging from the target income method to simulations using a CGE model. An example of a simple approach would be to set a target income for the North Korean people, with additional considerations for building the basic infrastructure in North Korea. Estimates of this kind can be found in Beck (2010), Choi (2011), and Lee and Kim (2012). Studies of Korean unification costs using a CGE model include those of Noland $(1996,1998)$, KINU (2011, 2013), KIEP (2014) and Cheong (2015).

CGE models have been widely used for estimating the impact of economic integration. A key issue in building a CGE model for North Korea is obtaining adequate data and information on its economy. Although no official IO table for North Korea is available, South Korean researchers have tried to estimate North Korean IO tables based on piecemeal information derived from various sources. "IO tables describe the sale and purchase relationships between producers and consumers within an economy. They can be produced by illustrating the flows between the sales and purchases (final and intermediate) of industry outputs or by illustrating the sales and purchases (final and intermediate) of

2) National unification implies the act of unifying or the state of being unified from two different countries in all institutional aspects, such as political, economic, educational and others. 
product outputs." (OECD STAN 2012) However, insufficient data are currently available for this purpose.

Shin (2009), Choi (2014) and Kim and Shin (2014) are examples of studies that attempted to estimate IO tables for North Korea. Choi (2014) estimated that the production inducement coefficients (Ed- 'production induced coefficients' is OK, but you use 'production inducement coefficients' elsewhere in the paper, and it's better to use just one form) are higher than those based on Chinese I-O (1978) and lower than those based on Eastern German I-O (1987). When the estimated North Korean I-O (2000) is compared with South Korea's periodical I-O from 1960 to 2010, the production inducement coefficient of the main industry in North Korea is found to be higher than South Korea's level in 1970 and lower than its level in 1980.

The unavailability of any official Social Accounting Matrix (SAM) and IO tables for North Korea prevents exact determination of the benefits and costs of national unification. Estimating a SAM or IO table of North Korea is beyond the scope of the present survey paper, but can be undertaken by a future follow-up research study. Another approach would be to introduce the North Korean economy into the GTAP database as one of the disaggregated countries (regions), which would constitute an important contribution to this resource. This task could be undertaken individually or in collaboration with the GTAP administrators, but the most important requirement for this is obtaining sufficient information on the North Korean economy to be able to build a database for the CGE model.

Considering the difficulties involved in collecting the various sets of data and balancing them in order to construct a dataset consistent with a CGE model for economic integration in Korea, a possible approach is to use the GTAP database and link the data for the Korea model in a multi-regional context. This necessitates building a dataset for the North Korean economy and organizing it so that it is consistent with the GTAP database. This can be inferred from Huff et al (2000), who acted as research staff for the GTAP database. Before building a CGE model that is suitable for estimating the impact of Korea unification, the data for the North Korean economy needs to be obtained.

\subsection{Minimum CGE data for a single region}

Huff et al (2000) suggested two kinds of data array formats that are necessary for building a CGE database: one for the recent versions of the GTAP database (version 5 and above, Unified Format in Table 1), and the other for the old versions (versions 4 and below, Original Format in Table 2). The arrays for the single-region IO table consist of six sets of 
data: UF implies 'usage of production factors' in input before tax , UP 'usage of production factors' in input after tax, OP 'usage of production inputs' with tax, MF 'imports of commodities', SSET 'sector names', and SMAP 'map from standard GTAP sectors'.

The dimensions of the data are the matrices of $(2 \mathrm{~g}+3)$ by $(\mathrm{g}+5)$. The row is $2 \mathrm{~g}+3$, where ' 3 ' implies the primary production factors of land, labor and capital, and ' $2 \mathrm{~g}$ ' means the two sets of intermediate production inputs of commodities, i.e., domestic commodities and imported commodities. The column is ' $\mathrm{g}+5$ ', where ' 5 ' is constructed in the column order of intermediate commodity usage (SECT in Table 3), household

consumption of commodities $(\mathrm{H})$, government consumption $(\mathrm{G})$, investment (I), changes in stocks $(\triangle K)$, and exports $(E)$. The data for 'OP' and 'MF' form a vector with dimension $\mathrm{g}$ of commodity outputs, with the inclusion and exclusion of tax, respectively.

\section{Table 1.}

Arrays for Single-Region Input-Output (IO) Tables: Unified Format

\begin{tabular}{c|c|l}
\hline & Dimensions & \multicolumn{1}{c}{ Description } \\
\hline UF & $2 \mathrm{~g}+3, \mathrm{~g}+5$ & Usage of input $\mathrm{i}$ in use $\mathrm{u}$, commodity tax excluded \\
$\mathrm{UP}$ & $2 \mathrm{~g}+3, \mathrm{~g}+5$ & Usage of input i by use $\mathrm{u}$, commodity tax inclusive \\
$\mathrm{OP}$ & $\mathrm{g}$ & Output of sector i, non-commodity indirect tax included \\
$\mathrm{MF}$ & $\mathrm{g}$ & Imports of commodity $\mathrm{i}$, import duties excluded \\
$\mathrm{SSET}$ & $\mathrm{g}$ & Sector names \\
$\mathrm{SMAP}$ & $\mathrm{gg}$ & Map from standard GTAP sectors \\
\hline $\mathrm{g}$ & Number of sectors in IO table \\
$\mathrm{gg}$ & Number of sectors in GTAP standard sectoral classification \\
\hline
\end{tabular}

Source : Huff, McDougall and Walmsley (2000) p. 3

The original format has 29 data sets of 5 matrices and 24 vectors, which requires more labor and time to build the data than the unified format. Four of these 5 matrices are made up of two for the intermediate commodities of domestically produced ones (AI01 with the dimension of gxg) and imported ones (AI02 with the dimension of gxg), and two for the taxes of the domestically produced ones (AI16) and imported ones (AI17). The matrix of $\mathrm{g} \times \mathrm{g}$ covers all intermediate products for production. The vectors of dimension $\mathrm{g}$ represent investment, household consumption, government consumption, change in capital stocks, imports, exports, taxes, employment of labor, capital and land, import duties and others. 
Table 2.

Arrays for Single-Region Input-Output (IO) Tables: Original Format

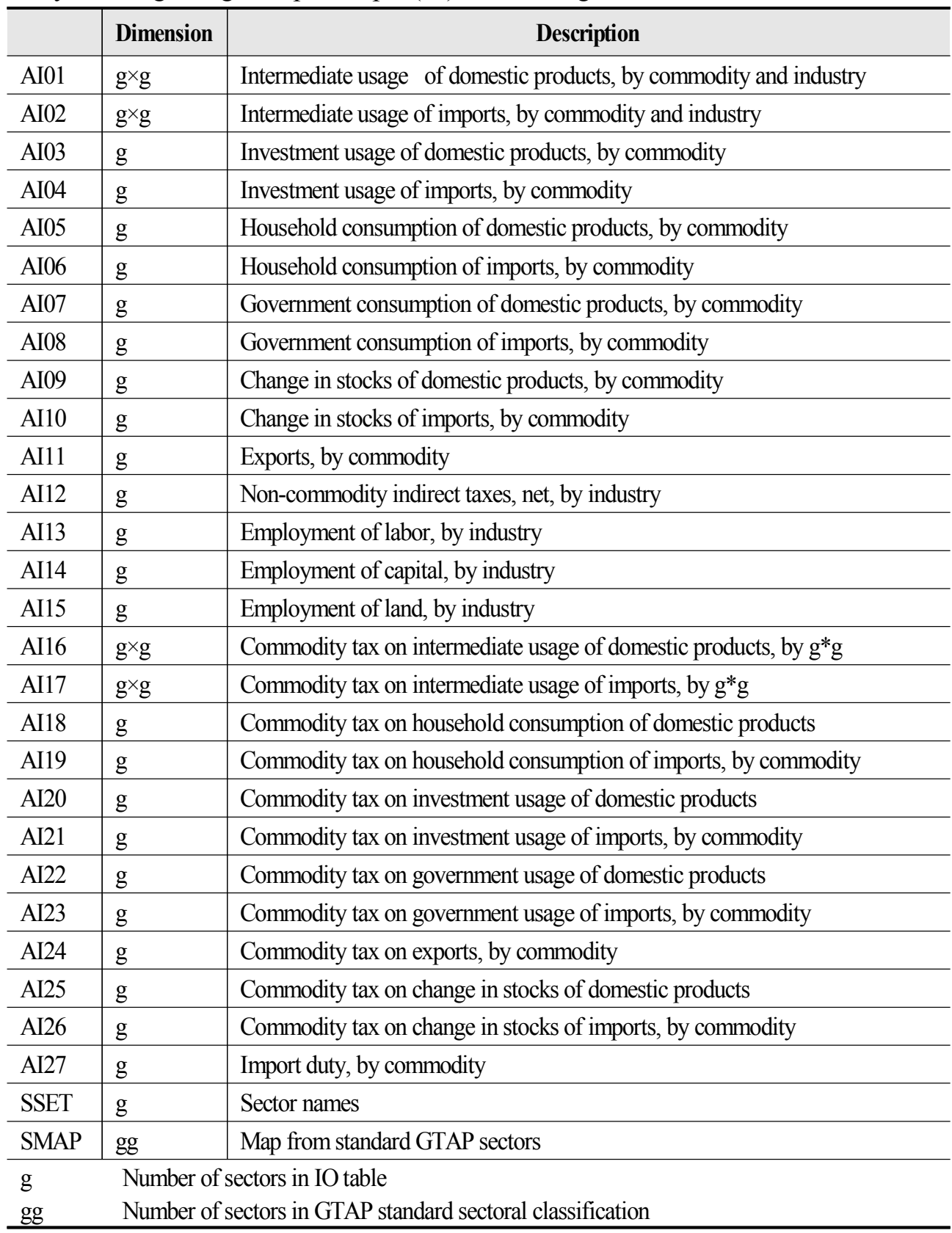

Source : CALDER et al. (1993). Recited from Huff, McDougall and Walmsley (2000) p. 5 
The relationship between the pre-commodity tax and post-commodity-tax usage values matrices can be seen in Table 3, which depicts the relationship between UF and UP in Table 1 with those data arrays in Table 2. The first column is the commodity inputs for production in the vertical order of domestic commodity inputs (DSECT in Table 3), imported ones (MSECT), and 3 primary production factors of labor, land and capital. The commodities will be used in the order of the column of dimension 5 in ' $\mathrm{g}+5$ ' Table 1 ,

which are SECT (intermediate inputs), household consumption of commodities $(\mathrm{H})$, government consumption $(\mathrm{G})$, investment $(\mathrm{I})$, changes in stocks $(\triangle \mathrm{K})$, and exports $(\mathrm{E})$.

Table 3.

Matrix of commodity usage values

\begin{tabular}{|c|c|c|c|c|c|c|}
\hline \multicolumn{7}{|c|}{ Matrix of pre-commodity-tax usage values (UF) } \\
\hline & SECT & Investment & Consumption & Government & $\begin{array}{c}\text { Change in } \\
\text { Stocks }\end{array}$ & Exports \\
\hline DSECT & $\mathrm{AI} 01$ & $\mathrm{AI} 03$ & AI05 & AI07 & AI09 & AI11 \\
\hline MSECT & $\mathrm{AI} 02$ & $\mathrm{AI} 04$ & AI06 & AI08 & AI10 & 0 \\
\hline Labor & AI13 & 0 & 0 & 0 & 0 & 0 \\
\hline Capital & AI14 & 0 & 0 & 0 & 0 & 0 \\
\hline Land & AI15 & 0 & 0 & 0 & 0 & 0 \\
\hline \multicolumn{7}{|c|}{ Matrix of post-commodity-tax usage values (UP) } \\
\hline & SECT & Investment & Consumption & Government & $\begin{array}{c}\text { Change in } \\
\text { Stocks }\end{array}$ & Exports \\
\hline DSECT & $\mathrm{AI} 01+\mathrm{AI} 16$ & $\mathrm{AI} 03+\mathrm{AI} 20$ & $\mathrm{AI} 05+\mathrm{AI} 18$ & $\mathrm{AI} 07+\mathrm{AI} 22$ & AI09+AI25 & $\mathrm{AI} 11+\mathrm{AI} 24$ \\
\hline MSECT & AI02+AI17 & AI04+AI21 & AI06+AI19 & AI08+AI23 & AI10+AI26 & 0 \\
\hline Labor & AI13 & 0 & 0 & 0 & 0 & 0 \\
\hline Capital & AI14 & 0 & 0 & 0 & 0 & 0 \\
\hline Land & AI15 & 0 & 0 & 0 & 0 & 0 \\
\hline
\end{tabular}

Source : Combined table of Tables A6 and A7 in Huff, McDougall and Walmsley (2000, p. 24) 
Tables 1-3 reveal that a lot of data are needed to build a simple single-region model (Ed- confirm that you don't mean 'one simple regional model'). Much more data will be required for a multi-country CGE model. The required data are the full version of the IO table, taxes and tariffs by commodity sectors defined in the IO table, the usage of primary production factors such as land, labor and capital, information on the household consumption of commodities, government consumption, investment, changes in stocks, and trade of imports and exports. The dimensions of SAM for a representative region and mapping transactions are given in Tables $\mathrm{A} 2$ and $\mathrm{A} 3$, respectively. It is necessary to check the availability of the data on the North Korean economy. This assessment is made in the following section.

\section{Leontief inverse coefficients for North Korean economy}

The major difficulties involved in conducting a CGE simulation are building a CGE model and constructing a compatible database. The former task can be a theoretical work and researchers can choose one of the existing models and modify it for the purpose of their research. However, the latter task poses a fundamental problem, due to the lack of data on the North Korean economy. Although piecemeal information on the economy of North Korea is reported in the mass media and economic journals, its accuracy is questionable and no systematic information is available.

The Bank of Korea (BOK), the central bank of South Korea, has been a leading institute studying the North Korean economy, publishing research papers irregularly. BOK has published estimates of the economic growth rates of North Korea since 1991, based on information provided by various sources on economic activities in North Korea. However, its estimates of the economic growth rates of North Korea depend heavily on the economic system of South Korea. BOK (2014) reminds the readers of its papers on North Korea that it used South Korea's system of good prices, added value and other items in estimating the economic growth rates, industrial structure, economic scale, per capita Growth National Income (GNI), etc. BOK (2014) states that its reports can be useful in understanding the overall economic activities in North Korea, implying that the bank is not sure about the accuracy of the North Korean economy. First of all, considering the centrally planned economic practices in North Korea, the pricing systems of the two countries will be quite different, regardless of the different GDP trends of the two countries shown in Figure 1. 


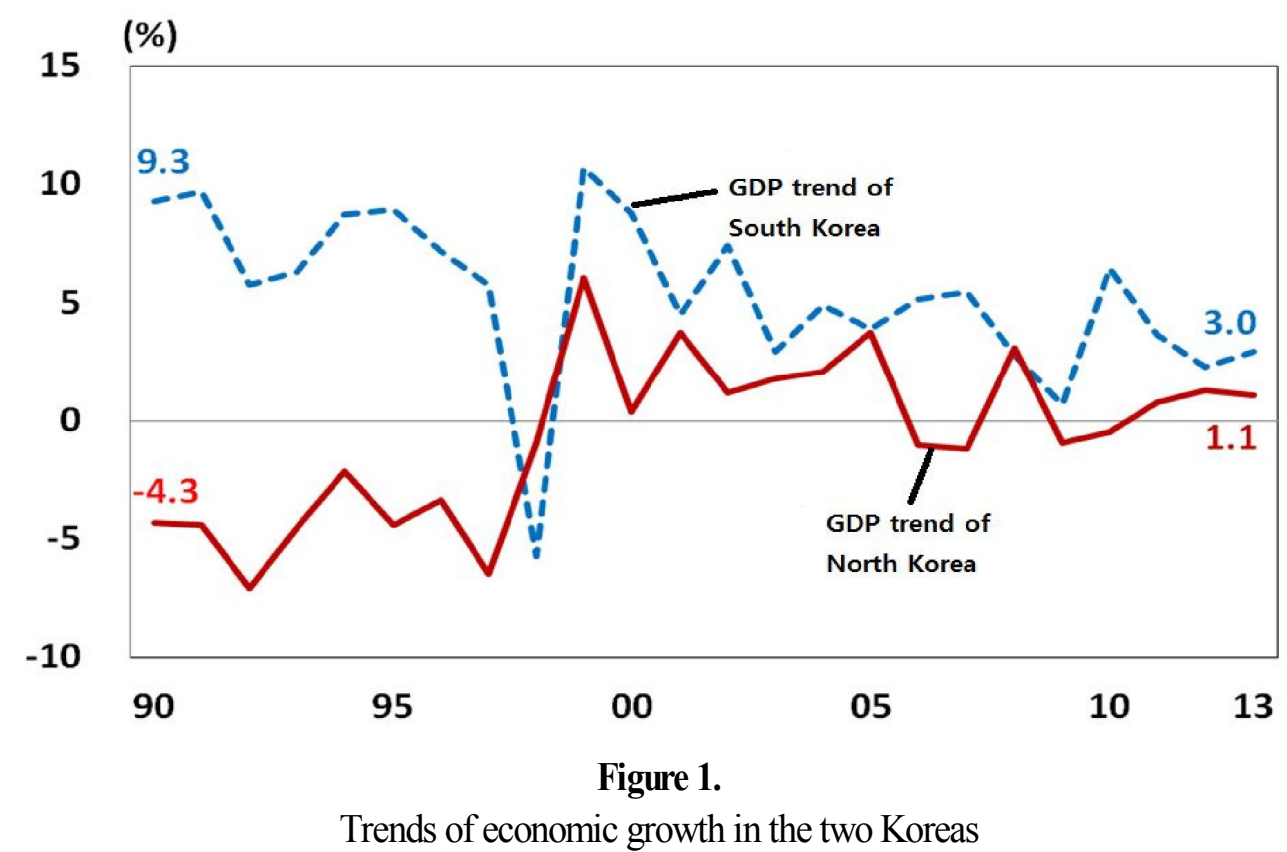

Source: BOK (2014) p.1

A few researchers have published IO tables or SAMs of North Korea. Shin (2009) estimated a SAM and an IO table for the North Korean economy in order to analyze the North Korean economy. He applied "SAM multiplier analysis to the computation of the effects of exogenous injections into the North Korean economy. The cross entropy principle is applied to find its IO table, given the incomplete information and statistics on the North Korean economy."

Two further papers on North Korea's IO table were published in 2014 (Choi (2014) and Kim and Shin (2014)), yet showed different results (Ed- you don't need the paper titles; that's the purpose of the Reference section below). Choi (2014) collected old IO tables of former socialist countries such as China, East Germany and Vietnam in assembling the North Korean IO table.(Ed- not 'On the other hand' because it's the same study). To minimize the CE entropy, Choi attempted to estimate the IO of North Korea using Vietnam's IO table, and compared the production inducement coefficients with those in China's 1978 IO table and Eastern German's 1989 IO table. Choi concluded that North Korea's production coefficients for major production sectors are "higher than South Korea's level in 1970 and lower than its level in 1980."

The study by Kim and Shin (2014) seems to be an extension of a study by the Korea Research Institute for Human Settlements (KRIHS, 2013). 3) (Ed- again, you don't need the paper title because it's in the Reference section below) Their paper was designed to 
estimate the economic effects of building a key infrastructure in North Korea, ${ }^{4)}$ but the beauty of their study is that it includes their own IO table for the North Korean economy.

The IO coefficients of these two studies are different, because of the differences in the base year, data source, calibration method and research purpose. However, it is not easy to compare the accuracy of the two, due to the lack of information provided by the authors. Considering that an IO table is the key requirement for building a CGE model and its database, researchers have to use the available information. Rather than comparing the coefficients, the present paper adopts the method of averaging the coefficients in Choi (2014) and Kim and Shin (2014) by grouping similar sectors in the two papers, although this is not a satisfactory approach.

Choi (2014) disaggregated the North Korean economy into 7 sectors (agriculture and fishery, mining, light manufacture, heavy industry, electricity-gas-water, construction, other services), whereas Kim and Shin (2014) used 11 sectors (agriculture and fishery, mining, light manufacture, coal and petroleum, heavy industry, utility, construction, sales, transportation, government service, other services). In order to combine the two sets of IO coefficients in Choi (2014) and Kim-Shin (2014), in this study, we attempt to average the coefficients while taking into account their different industrial classifications. That is, the different sectors in the two sets of coefficients are coordinated. For example, the sector of electricity-gas-water in Choi (2014) is regarded as the utility sector in Kim and Shin (2014), and other services in Choi (2014) represents the four sectors of sales, transportation, government service and other services in Kim and Shin (2014). The averaged Leontief coefficients of the IO table for the North Korean economy are given in Table 4.

\section{Table 4.}

Leontief inverse coefficients for the North Korean economy

\begin{tabular}{c|c|c|c|c|c|c|c}
\hline From $\backslash$ to & $\begin{array}{c}\text { Agriculture } \\
\text { and Fishery }\end{array}$ & Mining & $\begin{array}{c}\text { Light } \\
\text { Manufacture }\end{array}$ & $\begin{array}{c}\text { Heavy } \\
\text { industry }\end{array}$ & $\begin{array}{c}\text { Electricity, } \\
\text { Gas and } \\
\text { Water }\end{array}$ & Construction & Services \\
\hline $\begin{array}{c}\text { Agriculture } \\
\text { and Fishery }\end{array}$ & 1.62 & 0.10 & 0.87 & 0.06 & 0.00 & 0.03 & 0.07 \\
\hline Mining & 0.04 & 0.05 & 0.04 & 1.16 & 0.15 & 0.20 & 0.40 \\
\hline $\begin{array}{c}\text { Light } \\
\text { Manufacture }\end{array}$ & 0.52 & 0.08 & 1.59 & 0.31 & 0.02 & 0.30 & 0.40 \\
\hline
\end{tabular}

3) The calibrated IO Table for North Korea by Kim and Shin (2014) is given in Table A1.

4) They estimated the total investment expenditure required in key infrastructures such as highways, railroads and industrial complexes in North Korea to be 9.35 billion US\$, and that this would yield a total output of 20.30 billion US\$ for North Korea annually, and would increase South Korea's GDP by 2.16 billion US\$ due to the investment in North Korea. 


\begin{tabular}{c|c|c|c|c|c|c|c}
\hline From $\backslash$ to & $\begin{array}{c}\text { Agriculture } \\
\text { and Fishery }\end{array}$ & Mining & $\begin{array}{c}\text { Light } \\
\text { Manufacture }\end{array}$ & $\begin{array}{c}\text { Heavy } \\
\text { industry }\end{array}$ & $\begin{array}{c}\text { Electricity, } \\
\text { Gas and } \\
\text { Water }\end{array}$ & Construction & Services \\
\hline $\begin{array}{c}\text { Heavy } \\
\text { industry }\end{array}$ & 0.61 & 0.29 & 0.48 & 3.47 & 0.17 & 1.68 & 1.23 \\
\hline $\begin{array}{c}\text { Electricity, } \\
\text { Gas and Water }\end{array}$ & 0.03 & 0.13 & 0.10 & 0.35 & 0.13 & 0.02 & 0.19 \\
\hline Construction & 0.04 & 0.01 & 0.01 & 0.02 & 0.02 & 0.00 & 1.12 \\
\hline Other Services & 0.20 & 0.29 & 0.28 & 0.51 & 0.05 & 0.35 & 0.74 \\
\hline
\end{tabular}

Because of the differences in the base year, data source and analysis method, the Leontief coefficients differ between the two papers, while there are substantial similarities in the scales of the coefficients. However, a noticeable difference is the excessively small coefficient for services, which is 0.74 in the matrix of the services row and the services column. The relevant coefficients of the sample countries in section 4 are bigger than 20 . While it is not possible to infer the background for this difference, it does suggest that the information set on the North Korean economy differs substantially between the two studies.

\section{IO tables of sample economies}

Since North Korea is the most isolated country in the world, its economic structure may be different from those of other countries, regardless of their developmental stage. Further, North Korea has maintained a planned economic system, which may explain its small coefficient for services. In this section, we will compare the inverse coefficients of North Korea with those of South Korea and China, and then compare those of the 5 transitional economies selected in this paper, in an attempt to find one with a similar IO structure to that of North Korea. Since the economies in these counties have been operating for more than 20 years following the collapse of the Soviet system, the impact of their planned economic system has almost but not entirely disappeared.

The GTAP database has a format for representing the data for disaggregated countries, which is consistent with the model specification of GTAP, while not providing country-specific IO tables. Therefore, this paper relies on the STAN (OECD Structural Analysis Statistics STAN I-O Inverse Matrix (Total), 2012), which provides IO tables for about 40 countries. Most of these are EU members, transitional economies in East Europe and Asian countries such as China, Japan, Korea and Vietnam. 


\subsection{Comparison with Korea and China}

A comparison of the inverse coefficients of North Korea with those of South Korea and China is given as a reference. North Korea's coefficients are smaller than those of South Korea (Table 5) and China (Table 6) in most elements of the matrix, with some exceptions, such as for agriculture and fishery. The Leontief Inverse matrix, which is calculated with (I-A)^(-1), represents the growth of output in each sector, disaggregated due to the unit growth of final demand. Here, $\mathrm{A}$ is an input-coefficient matrix from the I-O total (domestic and imported) table.

\section{Table 5.}

Leontief inverse coefficients for South Korea

\begin{tabular}{c|c|c|c|c|c|c|c}
\hline & $\begin{array}{c}\text { Agriculture } \\
\text { and Fishery }\end{array}$ & Mining & $\begin{array}{c}\text { Light } \\
\text { Manufacture }\end{array}$ & $\begin{array}{c}\text { Heavy } \\
\text { industry }\end{array}$ & $\begin{array}{c}\text { Electricity, } \\
\text { Gas and } \\
\text { Water }\end{array}$ & Construction & Services \\
\hline $\begin{array}{c}\text { Agriculture } \\
\text { and Fishery }\end{array}$ & 1.12 & 0.01 & 0.88 & 0.09 & 0.00 & 0.01 & 0.32 \\
\hline Mining & 0.08 & 1.12 & 1.72 & 1.45 & 0.49 & 0.12 & 0.91 \\
\hline $\begin{array}{c}\text { Light } \\
\text { Manufacture }\end{array}$ & 0.47 & 0.27 & 13.03 & 3.93 & 0.49 & 0.34 & 3.27 \\
\hline $\begin{array}{c}\text { Heavy } \\
\text { industry }\end{array}$ & 0.22 & 0.45 & 2.65 & 20.60 & 0.35 & 0.95 & 3.34 \\
\hline $\begin{array}{c}\text { Electricity, } \\
\text { Gas and Water }\end{array}$ & 0.03 & 0.04 & 1.90 & 2.27 & 1.25 & 0.05 & 2.77 \\
\hline Construction & 0.01 & 0.00 & 1.49 & 0.05 & 0.01 & 1.00 & 0.20 \\
\hline Other Services & 0.34 & 0.35 & 4.12 & 4.93 & 0.41 & 0.50 & 20.31 \\
\hline
\end{tabular}

The sources of the IO tables have different types of sectoral disaggregation. The IO tables in the OECD STAN have 34 sectors, and these were aggregated into the same 7 sectors as those in Table 4, with one primary sector, one mining sector, two manufacturing sectors and three services sectors. The three services sectors are Utilities (Electricity, Gas and Water), Construction and Other Services. As mentioned above, the coefficients for other services in South Korea and China are much higher than those for North Korea. 
Table 6.

Leontief inverse coefficients for China

\begin{tabular}{c|c|c|c|c|c|c|c}
\hline & $\begin{array}{c}\text { Agriculture } \\
\text { and Fishery }\end{array}$ & Mining & $\begin{array}{c}\text { Light } \\
\text { Manufacture }\end{array}$ & $\begin{array}{c}\text { Heavy } \\
\text { industry }\end{array}$ & $\begin{array}{c}\text { Electricity, } \\
\text { Gas and } \\
\text { Water }\end{array}$ & Construction & Services \\
\hline $\begin{array}{c}\text { Agriculture } \\
\text { and Fishery }\end{array}$ & 1.25 & 0.04 & 1.48 & 0.56 & 0.03 & 0.05 & 1.00 \\
\hline Mining & 0.06 & 1.32 & 2.04 & 2.41 & 0.48 & 0.26 & 1.42 \\
\hline $\begin{array}{c}\text { Light } \\
\text { Manufacture }\end{array}$ & 0.41 & 0.34 & 13.96 & 5.08 & 0.54 & 0.51 & 5.76 \\
\hline $\begin{array}{c}\text { Heavy } \\
\text { industry }\end{array}$ & 0.13 & 0.45 & 2.40 & 19.17 & 0.46 & 0.97 & 4.86 \\
\hline $\begin{array}{c}\text { Electricity, } \\
\text { Gas and Water }\end{array}$ & 0.04 & 0.15 & 1.77 & 2.31 & 1.46 & 0.11 & 2.90 \\
\hline Construction & 0.00 & 0.00 & 1.18 & 0.03 & 0.00 & 1.01 & 0.13 \\
\hline Other Services & 0.24 & 0.38 & 3.42 & 4.58 & 0.46 & 0.52 & 20.43 \\
\hline
\end{tabular}

\subsection{Searching for a proxy economy}

Tables 5 and 6, which were used for the comparison with the data for Korea and China, were provided purely as a reference, although it is clear that these countries cannot be a good proxy country for North Korea in terms of the IO table, due to their structural differences. Similarly, the OECD countries are not relevant. Five non-OECD countries in the OECD STAN database that historically had a socialist economic system are Romania, Lithuania, Latvia, Bulgaria and Vietnam. These countries began their transition from a socialist planned economy to a capitalist market economy under democracy (Ed- incorrect, $\underline{\text { certainly }}$ in the case of Vietnam: Just earlier this year (2016) General Secretary Nguyen Phu Trong was re-elected as communist party chief, and hence the country's leader, as one-party rule continues in Vietnam. You need to modify your statement here). The Leontief inverse matrices of these 5 chosen sample countries are given in Tables 7-11, respectively.

This paper tries to choose a suitable country to use as a proxy economy for North Korea. KIEP (2014) chose Tanzania based on the size of its national GDP and the share of mining in its economy. However, this is not a good approach, since it does not consider the structure of the IO. Researchers can adjust the scale of economy by multiplying each element of a proxy economy in the GTAP database. This requires adept manipulation of the 
head array (HAR) formatted data, and the theory of the GTAP model.5)

Table 7.

Leontief inverse coefficients for Romania

\begin{tabular}{c|c|c|c|c|c|c|c}
\hline & $\begin{array}{c}\text { Agriculture } \\
\text { and Fishery }\end{array}$ & Mining & $\begin{array}{c}\text { Light } \\
\text { Manufacture }\end{array}$ & $\begin{array}{c}\text { Heavy } \\
\text { industry }\end{array}$ & $\begin{array}{c}\text { Electricity, } \\
\text { Gas and } \\
\text { Water }\end{array}$ & Construction & Services \\
\hline $\begin{array}{c}\text { Agriculture } \\
\text { and Fishery }\end{array}$ & 1.40 & 0.01 & 0.72 & 0.12 & 0.01 & 0.02 & 0.28 \\
\hline Mining & 0.05 & 1.32 & 0.94 & 1.07 & 0.32 & 0.10 & 0.51 \\
\hline $\begin{array}{c}\text { Light } \\
\text { Manufacture }\end{array}$ & 0.16 & 0.15 & 9.23 & 1.75 & 0.35 & 0.20 & 1.89 \\
\hline $\begin{array}{c}\text { Heavy } \\
\text { industry }\end{array}$ & 0.07 & 0.17 & 0.93 & 12.10 & 0.15 & 0.36 & 1.35 \\
\hline $\begin{array}{c}\text { Electricity, } \\
\text { Gas and Water }\end{array}$ & 0.06 & 0.18 & 2.82 & 3.37 & 1.25 & 0.14 & 3.97 \\
\hline \begin{tabular}{c} 
Construction \\
\hline Other Services
\end{tabular} & 0.03 & 0.06 & 1.87 & 0.44 & 0.07 & 1.13 & 0.72 \\
\hline
\end{tabular}

Table 8.

Leontief inverse coefficients for Lithuania

\begin{tabular}{c|c|c|c|c|c|c|c}
\hline & $\begin{array}{c}\text { Agriculture } \\
\text { and Fishery }\end{array}$ & Mining & $\begin{array}{c}\text { Light } \\
\text { Manufacture }\end{array}$ & $\begin{array}{c}\text { Heavy } \\
\text { industry }\end{array}$ & $\begin{array}{c}\text { Electricity, } \\
\text { Gas and } \\
\text { Water }\end{array}$ & Construction & Services \\
\hline $\begin{array}{c}\text { Agriculture } \\
\text { and Fishery }\end{array}$ & 1.18 & 0.01 & 0.55 & 0.11 & 0.01 & 0.01 & 0.14 \\
\hline Mining & 0.06 & 1.07 & 0.68 & 0.53 & 0.23 & 0.04 & 0.20 \\
\hline $\begin{array}{c}\text { Light } \\
\text { Manufacture }\end{array}$ & 0.37 & 0.21 & 9.41 & 1.97 & 0.24 & 0.11 & 1.34 \\
\hline $\begin{array}{c}\text { Heavy } \\
\text { industry }\end{array}$ & 0.20 & 0.16 & 1.20 & 13.53 & 0.17 & 0.29 & 1.32 \\
\hline $\begin{array}{c}\text { Electricity, } \\
\text { Gas and Water }\end{array}$ & 0.07 & 0.03 & 1.88 & 2.60 & 1.22 & 0.03 & 2.51 \\
\hline Construction & 0.01 & 0.01 & 1.47 & 0.14 & 0.02 & 1.14 & 0.10 \\
\hline Other Services & 0.57 & 0.29 & 3.89 & 4.37 & 0.30 & 0.32 & 18.25 \\
\hline
\end{tabular}

5) A subsequent follow-up research project would be to adjust the HAR data of the proxy economy. Since this needs a lot of data analysis and systemic tests before conducting a practical simulation, this approach is not included in this paper. 
Table 9.

Leontief inverse coefficients for Latvia

\begin{tabular}{c|c|c|c|c|c|c|c}
\hline & $\begin{array}{c}\text { Agriculture } \\
\text { and Fishery }\end{array}$ & Mining & $\begin{array}{c}\text { Light } \\
\text { Manufacture }\end{array}$ & $\begin{array}{c}\text { Heavy } \\
\text { industry }\end{array}$ & $\begin{array}{c}\text { Electricity, } \\
\text { Gas and } \\
\text { Water }\end{array}$ & Construction & Services \\
\hline $\begin{array}{c}\text { Agriculture } \\
\text { and Fishery }\end{array}$ & 1.42 & 0.03 & 0.85 & 0.38 & 0.02 & 0.04 & 0.30 \\
\hline Mining & 0.02 & 1.15 & 0.12 & 0.38 & 0.16 & 0.08 & 0.21 \\
\hline $\begin{array}{c}\text { Light } \\
\text { Manufacture }\end{array}$ & 0.22 & 0.18 & 9.92 & 2.35 & 0.19 & 0.25 & 1.83 \\
\hline $\begin{array}{c}\text { Heavy } \\
\text { industry }\end{array}$ & 0.14 & 0.14 & 1.13 & 13.77 & 0.14 & 0.44 & 1.46 \\
\hline $\begin{array}{c}\text { Electricity, } \\
\text { Gas and Water }\end{array}$ & 0.09 & 0.08 & 2.67 & 4.87 & 1.44 & 0.09 & 4.51 \\
\hline Construction & 0.06 & 0.04 & 2.15 & 0.76 & 0.08 & 1.40 & 1.00 \\
\hline Other Services & 0.78 & 0.80 & 4.65 & 7.36 & 0.62 & 0.86 & 23.18 \\
\hline
\end{tabular}

Table 10.

Leontief inverse coefficients for Bulgaria

\begin{tabular}{c|c|c|c|c|c|c|c}
\hline & $\begin{array}{c}\text { Agriculture } \\
\text { and Fishery }\end{array}$ & Mining & $\begin{array}{c}\text { Light } \\
\text { Manufacture }\end{array}$ & $\begin{array}{c}\text { Heavy } \\
\text { industry }\end{array}$ & $\begin{array}{c}\text { Electricity, } \\
\text { Gas and } \\
\text { Water }\end{array}$ & Construction & Services \\
\hline $\begin{array}{c}\text { Agriculture } \\
\text { and Fishery }\end{array}$ & 1.34 & 0.02 & 0.82 & 0.26 & 0.02 & 0.02 & 0.24 \\
\hline Mining & 0.13 & 1.17 & 1.85 & 1.83 & 0.50 & 0.14 & 0.71 \\
\hline $\begin{array}{c}\text { Light } \\
\text { Manufacture }\end{array}$ & 0.31 & 0.18 & 9.93 & 2.42 & 0.54 & 0.27 & 1.66 \\
\hline $\begin{array}{c}\text { Heavy } \\
\text { industry }\end{array}$ & 0.11 & 0.13 & 0.99 & 12.73 & 0.20 & 0.34 & 1.00 \\
\hline $\begin{array}{c}\text { Electricity, } \\
\text { Gas and Water }\end{array}$ & 0.09 & 0.24 & 3.25 & 3.86 & 1.16 & 0.10 & 3.25 \\
\hline Construction & 0.04 & 0.04 & 1.92 & 0.54 & 0.05 & 1.14 & 0.50 \\
\hline Other Services & 0.58 & 0.48 & 4.51 & 6.06 & 0.65 & 0.80 & 20.42 \\
\hline
\end{tabular}


Table 11.

Leontief inverse coefficients for Bulgaria

\begin{tabular}{c|c|c|c|c|c|c|c}
\hline & $\begin{array}{c}\text { Agriculture } \\
\text { and Fishery }\end{array}$ & Mining & $\begin{array}{c}\text { Light } \\
\text { Manufacture }\end{array}$ & $\begin{array}{c}\text { Heavy } \\
\text { industry }\end{array}$ & $\begin{array}{c}\text { Electricity, } \\
\text { Gas and } \\
\text { Water }\end{array}$ & Construction & Services \\
\hline $\begin{array}{c}\text { Agriculture } \\
\text { and Fishery }\end{array}$ & 1.51 & 0.01 & 1.67 & 0.52 & 0.01 & 0.04 & 0.89 \\
\hline Mining & 0.04 & 1.19 & 1.78 & 2.07 & 0.18 & 0.24 & 0.97 \\
\hline $\begin{array}{c}\text { Light } \\
\text { Manufacture }\end{array}$ & 0.27 & 0.08 & 14.27 & 5.27 & 0.19 & 0.37 & 3.63 \\
\hline $\begin{array}{c}\text { Heavy } \\
\text { industry }\end{array}$ & 0.08 & 0.19 & 1.90 & 19.55 & 0.14 & 1.00 & 2.67 \\
\hline $\begin{array}{c}\text { Electricity, } \\
\text { Gas and Water }\end{array}$ & 0.02 & 0.01 & 2.53 & 3.24 & 1.06 & 0.03 & 3.51 \\
\hline Construction & 0.02 & 0.03 & 2.28 & 0.37 & 0.02 & 1.22 & 0.67 \\
\hline Other Services & 0.20 & 0.13 & 3.21 & 4.16 & 0.12 & 0.35 & 18.48 \\
\hline
\end{tabular}

This section tries to determine the most similar IO table to that of North Korea out of these 5 countries. Section 3 revealed that the averaged IO data have excessively small coefficients for the other services sector. Therefore, the other services sector is excluded from the evaluation of the IO similarity.

A simple approach to evaluating the IO similarity among the IO tables is to sum the squares of the absolute differences between the coefficients of each element for North Korea and that of the sample economy. Table 12 presents the sums of the differences in the coefficients and the sums of the squares of the differences in the coefficients for the 7 economies discussed in this section. The sum of the squares of the differences in the coefficients ranges from 268 to 658 . The largest sum is found for Vietnam, whereas that for South Korea is smaller than those for China and Vietnam. The smallest sum was obtained for Romania, which is one of the poorest countries in the Eastern and Central Asia (EdRomania is in Europe!!). Thus, it can be inferred that Romania is a good proxy economy to use for North Korea, allowing for the possibility of minimizing the estimation errors.

(Ed- 'Romania is a good proxy economy'? Romania is in the EU; you've chosen an EU member country as a good proxy economy for North Korea!) 
Table 12.

Sum of squares of coefficient differences

\begin{tabular}{c|c|c}
\hline & Sum of coefficient differences & Sum of squares of coefficient differences \\
\hline Romania & 43.2 & 268.32 \\
\hline Lithuania & 40.91 & 296.32 \\
\hline Latvia & 47.23 & 339.81 \\
\hline Bulgaria & 48.66 & 311.20 \\
\hline Vietnam & 63.40 & 657.94 \\
\hline China & 62.46 & 625.51 \\
\hline South Korea & 48.39 & 503.08 \\
\hline
\end{tabular}

\section{Conclusion}

One of the most surprising results of this paper is that, among the 7 countries studied herein, Vietnam is the most different from North Korea in terms of its IO structure. (Edactually, the most surprising study result is about Romania) Choi (2014) attempts to estimate North Korea's I-O for 2011 using the Vietnamese 2000's I-O. Although this paper is based on the coefficients of Choi (2014) and Kim-Shin (2014), we found Vietnam that showed the greatest difference from the averaged IO table. This may be due to the time lag, in that Choi inferred the 2011 North Korean IO table based on the 2000 Vietnamese IO table.

The GTAP database has more than 50 developing countries, but not all of them can be considered for use as a proxy economy in this paper, because the IO tables are available in the OECD STAN for only some of these countries. A more fundamental issue, however, is whether the existing IO tables for the North Korean economy are accurate. Small differences can be accepted due to the base year, sectoral disaggregation, research purpose, and others, so researchers should pay more attention to choosing a proxy country for the North Korean economy.

National unification is a compelling issue, and South Korea should be prepared to deal with any situation. However, there are wide differences in the impacts of unification across studies. It will be difficult for the country to build a national consensus on the compelling issues in this case, and it is desirable for a national think-tank to compile existing studies and assess those academically, producing most probable estimates in order to reduce the confusion on the issue. 


\section{References}

Bank of Korea (2014), "Estimation Results of North Korea's Economic Growth in 2013". Seoul: Bank of Korea

Beck, Peter M. (2010), "Contemplating Korean Reunification", The Wall Street Journal, January 4 (Retrieved 8 April 2015)

Cheong, Inkyo (2015), "Estimation of Benefits and costs of Korea's unification", Journal of International Logistics and Trade 13(1)

Cho, Dongho(2010), "Desirable discussion on the costs of unification" Jeju Peace Institute

Choi, Joonook(2011), How to finance unification costs?, Seoul: KIPF

Choi, Jiyoung(2014), "A study on estimation of the Input-output table for the North Korea economy”, BIKYOKYONGJAEYONGU Vol. 21, No. 2

Goldman Sachs (2009), "A United Korea? Reassessing North Korea Risks (Part I), Goldman Sachs Global Economics

Huff, Karen, Robert McDougall and Terrie Walmsley (2000), "Contributing Input-Output Tables to the GTAP Data Base", GTAP Technical Paper No. 1

Hyundai Research Institute (2009), Recent Trend in Development of North Korea's Mineral Resources and the Implications (in Korean), by Haejung Lee

Kim, Sukjin, Sukgi Lee, Kaehwan Kim and Doohee Lee (2008), Industrial development strategy based on the experience of transition economies, Seoul: KIET

Kim, Changguen (2014), "Economic performance of German unification and research trend in German unification", JRI Research Series 4

Kim, Euijune and Hyewon Shin (2014), "Impact Analysis of Economic Linkages of South Korea with North Korea Using a CGE Model”, presented at the 54th European Regional Science Association Congress in St Petersburg, Russia, August 26-29, 2014. 
Korea Institute for National Unification (KINU, 2011), "New approach on the benefits and costs of unification: Comprehensive research factor and the search for alternative approach", Comprehensive research on the benefits and costs of unification, Vol. 11, No. 1

Korea Development Institute (KDI, 2010), "Future vision 2040”, presented at the Future Planning Committee, $7^{\text {th }}$ meeting

KDI(2013), A Study on Economic Integration between South Korea and North Korea: Long-term development strategy for North Korea

Korea Institute of International Economic Policy (KIEP, 2014), "Effects of Economic Integration between South Korea and North Korea", July. In Korean.

Korea Research Institute for Human Settlements (KRIHS, 2013), "Major development projects for the integrated Korean Peninsula", Joint Research by KRIHS

Lee, Kwangsik and Kownsik Kim(2012), "Analysis on the studies on unification: BC of unification costs and the network of unification policy", Public policy and administration of national agenda, Vol. 6, No. 2, Dankook University

Lee, Seung Hyun and Kim, Kap-sik(2011), "The Issues and Alternatives on the Reunification Cost of the Korean Peninsula", Policy Studies, Winter 2011

Lee, Youngsun(1992), "Scenario approach for the economic effects and BC analysis of unification in Korea", Seoul, Institute of East and West Studies, Yonsei University

Leontief, W. (1936), "Quantitative Input and Output Relations in the Economic Systems of the United States", The Review of Economics and Statistics, pp.105-125.

Noland, M. (1996). "Some unpleasant arithmetic concerning unification" (No. 96). Institute for International Economics.

Noland, Marcus, Sherman Robinson, and Li-Gang Liu(1997), "Calibrating the Costs (and Benefits) of Unification." Korean Economic Integration, Washington: Institute for International Economics 
McDonald, Scott and Karen Thierfelder (2004) "Deriving a Global Social Accounting Matrix from GTAP Versions 5 and 6 Data GTAP", GTAP Technical Paper No. 22

Marcus Noland, Sherman Robinson, Li-Gang Liu(1998), "The Costs and Benefits of Korean Unification", Working Paper 98-1, Peterson Institute for International Economics

RAND(2005), National Defense Research Institute, North Korean ParadoxesCircumstance, Costs and Consequences of Korean Unification, by Wolf, Charles

SERI(2005), "North Korean economy and current state of South-North economic cooperation", CEO information.

Shin, D. C.(2009), "The Estimation of a Social Accounting Matrix for The North Korean Economy and Its Application" Applied Economics 11(1), Korean Association of Applied Economics

Shin, Changmin(2010), "Costs of unification and its benefits", KINU Seminar Proceeding 10-03, Seoul: KINU

Sung, Hankyung(2014), "The analysis of costs and benefits of unification in Korea under various scenarios", presented at the seminar organized by KIEP (Lotte Hotel, November 5)

Wolf, Charles(2010), "The Cost Of Reuniting Korea”, Forbes, March 15

Wolf, Holger "Korean unification: Lessons from Germany" Peterson Institute for International Economics.(Retrieved from www.piie.com November 19 2014) 


\begin{tabular}{|c|c|c|c|c|c|c|c|c|c|c|c|c|c|c|c|c|c|}
\hline & $\begin{array}{l}\text { 言 } \\
\text { 言 }\end{array}$ & $\stackrel{\circ}{\circ}$ & $\underset{\forall}{\stackrel{\Xi}{ғ}}$ & $\hat{\widehat{b}}$ & 售 & 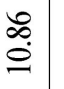 & $\vec{i}$ & & $\stackrel{t}{0}$ & $\exists$ & 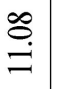 & & तi & & & & \\
\hline & $\begin{array}{l}\text { 䓂 } \\
\text { 童 }\end{array}$ & $\overline{3}$ & ఫ్తి & $\begin{array}{c}\infty \\
\tilde{c} \\
\tilde{c}\end{array}$ & $\bar{\delta}$ & E. & 8 & 8 & 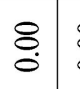 & 8 & 8 & 8 & $\stackrel{\infty}{\stackrel{\leftrightarrow}{\oplus}}$ & & & & \\
\hline & 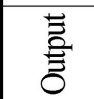 & $\underset{\infty}{\infty}$ & $\begin{array}{c}\Delta \\
c\end{array}$ & 怘 & \begin{tabular}{|l|} 
tud \\
|
\end{tabular} & 总 & $\stackrel{\text { ¿े }}{\mathrm{i}}$ & $\begin{array}{c}\tilde{\infty} \\
\stackrel{+}{*}\end{array}$ & $\stackrel{ \pm}{*}$ & 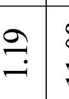 & 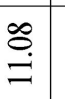 & $\stackrel{2}{-}$ & ָิ & & & & \\
\hline & 咅 & 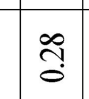 & ¿̊ & $\stackrel{m}{0}$ & \begin{tabular}{|l} 
\\
0 \\
0
\end{tabular} & స్ & $\stackrel{8}{8}$ & $\begin{array}{l}8 \\
0 \\
0\end{array}$ & $\stackrel{8}{0}$ & 8 & : & $\stackrel{8}{0}$ & $\stackrel{8}{0}$ & & & & \\
\hline & 落 & 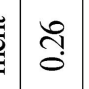 & $\underset{-}{\overrightarrow{-}}$ & $\begin{array}{l}8 \\
0\end{array}$ & $\begin{array}{l}8 \\
0\end{array}$ & gू & 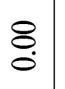 & 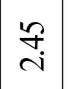 & $\stackrel{0}{0}$ & 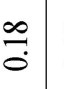 & \&. & $\stackrel{m}{0}$ & $\overrightarrow{i n}$ & & & & \\
\hline & 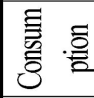 & {$\left[\begin{array}{l}n \\
i\end{array}\right.$} & $\stackrel{\partial}{\circ}$ & $\stackrel{f}{+}$ & $\begin{array}{l}8 \\
0\end{array}$ & $\stackrel{5}{\circ}$ & $\stackrel{8}{\circ}$ & 8 & $\stackrel{0}{\circ}$ & $\hat{\tilde{s}}$ & $\stackrel{\circ}{:}$ & $\vec{\odot}$ & బิ & & & & \\
\hline & 音 & $\stackrel{\vec{i}}{\vec{i}}$ & $\underset{i}{\stackrel{i}{i}}$ & 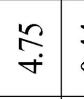 & 声 & Fे. & $\stackrel{\mathcal{F}}{-}$ & $\underset{\text { I }}{\text { I }}$ & $\stackrel{m}{\circ}$ & ț & $\stackrel{8}{\circ}$ & $\ddot{0}$ & 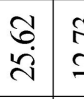 & 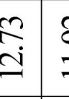 & $\stackrel{\Omega}{=}$ & 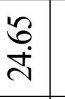 & तิ \\
\hline & $=$ & $\stackrel{8}{0}$ & $\stackrel{8}{0}$ & $\stackrel{0}{\circ}$ & $\mid \begin{array}{l}0 \\
0\end{array}$ & $\bar{\Xi}$ & $\tilde{o}_{0}$ & $\stackrel{\infty}{0}$ & $\stackrel{8}{\circ}$ & $\stackrel{8}{8}$ & $\stackrel{8}{\circ}$ & $\stackrel{0}{\circ}$ & ఝू. & $\begin{array}{c}\mathscr{c}_{0}^{\circ} \\
\end{array}$ & ִָ & $\stackrel{\Xi}{-}$ & $\stackrel{8}{\leftrightarrows}$ \\
\hline & $\subseteq$ & : & $\stackrel{\leftrightarrow}{0}$ & fo & $\overrightarrow{\dot{\theta}}$ & $\stackrel{q}{\stackrel{q}{*}}$ & ֻ̊̆ & $\underset{i}{\stackrel{i}{i}}$ & 8 & $\overline{0}$ & 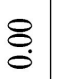 & $\stackrel{\circ}{0}$ & $\stackrel{2}{n}$ & $\left.\begin{array}{c}\infty \\
\hdashline \\
i\end{array}\right]$ & $\overline{0}$ & 总 & 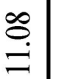 \\
\hline & $a$ & $\stackrel{8}{0}$ & $\stackrel{8}{0}$ & $\stackrel{0}{\circ}$ & $\frac{0}{0}$ & ¿े & 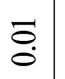 & 8 & $\stackrel{8}{\circ}$ & $\stackrel{\vdots}{\circ}$ & 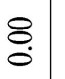 & $\stackrel{8}{\circ}$ & $\begin{array}{l}g \\
\delta\end{array}$ & तે & $\begin{array}{l}9 \\
0 \\
0 \\
0\end{array}$ & 范 & $\stackrel{9}{g}$ \\
\hline & $\infty$ & $\stackrel{8}{0}$ & $\begin{array}{l}8 \\
0\end{array}$ & $\begin{array}{l}8 \\
0\end{array}$ & $\begin{array}{l}8 \\
0\end{array}$ & $\stackrel{8}{0}$ & $\stackrel{8}{0}$ & $\stackrel{8}{0}$ & $\stackrel{8}{0}$ & $\stackrel{8}{0}$ & $\stackrel{8}{0}$ & $\stackrel{8}{\circ}$ & $\vec{c}$ & 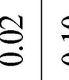 & $\frac{9}{0}$ & $\stackrel{9}{0}$ & $\stackrel{t}{\circ}$ \\
\hline & r & 范 & $\frac{9}{0}$ & 告 & $\tilde{a}_{0}$ & $\underset{I}{\stackrel{I}{*}}$ & $\overline{0}$ & $\begin{array}{l}8 \\
0\end{array}$ & $\bar{\Delta}$ & $\frac{n}{0}$ & : & $\stackrel{0}{\circ}$ & 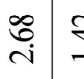 & I: & $\begin{array}{r}\stackrel{E}{0} \\
0\end{array}$ & $\overrightarrow{\mathrm{i}}$ & 安 \\
\hline \& & 6 & $\stackrel{8}{0}$ & $\begin{array}{l}\infty \\
\vdots \\
\vdots\end{array}$ & $\mid \begin{array}{l}0 \\
0 \\
0\end{array}$ & $\stackrel{g}{\dot{\sigma}}$ & $\stackrel{0}{\circ}$ & స్ & $\mid \begin{array}{l}t \\
0 \\
0\end{array}$ & 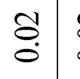 & ठٌ & \begin{tabular}{l}
8 \\
\hdashline \\
\end{tabular} & $\begin{array}{l}\text { to } \\
\dot{0}\end{array}$ & \begin{tabular}{l|c}
$\Omega$ \\
$\delta$ \\
\end{tabular} & तై & 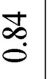 & $\stackrel{9}{\rightrightarrows}$ & ટે \\
\hline & in & $\stackrel{\infty}{0}$ & $\stackrel{\infty}{\dddot{2}}$ & $\mid \begin{array}{c}\infty \\
0 \\
0\end{array}$ & $\begin{array}{l}t \\
\dot{0}\end{array}$ & $\underset{ғ}{\ni}$ & 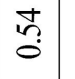 & $\mid \begin{array}{l}t \\
0 \\
0\end{array}$ & $\stackrel{8}{\circ}$ & 号 & $\stackrel{8}{\circ}$ & $\stackrel{7}{\circ}$ & $\begin{array}{lll}\bar{\sigma} & \Omega \\
-\end{array}$ & $\stackrel{\infty}{=} \varsubsetneqq$ & $\stackrel{8}{-}$ & $\stackrel{\vec{m}}{\vec{m}}$ & 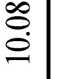 \\
\hline & + & $\stackrel{8}{8}$ & $\frac{2}{80}$ & : & $\bar{o}$ & $\stackrel{8}{8}$ & $\stackrel{8}{\circ}$ & \begin{tabular}{|}
8 \\
0 \\
0
\end{tabular} & $\stackrel{8}{0}$ & $\bar{o}$ & $\begin{array}{l}8 \\
0\end{array}$ & $\stackrel{8}{\circ}$ & $\stackrel{\infty}{\circ}$ & $\bar{\Xi}$ & 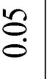 & 号 & 范 \\
\hline$\stackrel{0}{\pi}$ & $m$ & $\exists$ & $\begin{array}{c}\tilde{O} \\
\dot{O}\end{array}$ & $\frac{\infty}{i}$ & $\bar{o}$ & : & $\frac{n}{0}$ & $\bar{o}_{0}$ & $\stackrel{d}{\circ}$ & : & $\stackrel{8}{8}$ & $\begin{array}{l}\tilde{a} \\
\dot{0}\end{array}$ & $\begin{array}{ll} \\
g\end{array}$ & 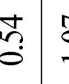 & $\stackrel{\leftrightarrow}{-}$ & $\stackrel{\Xi}{-}$ & s. \\
\hline 2 & a & $\stackrel{2}{0}$ & $\begin{array}{c}\tilde{O} \\
\dot{0}\end{array}$ & $\stackrel{ \pm}{0}$ & $\begin{array}{l}0 \\
\dot{0}\end{array}$ & ఝి & $\stackrel{\infty}{0}$ & $\bar{\Xi}$ & $\stackrel{d}{\circ}$ & 菅 & $\stackrel{8}{8}$ & $\stackrel{a}{\dot{o}}$ & $\stackrel{9}{\rightrightarrows}$ & 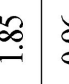 & 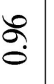 & $\overrightarrow{\vec{\sigma}_{\mathrm{i}}}$ & 㚐 \\
\hline 㐔 & - & $\stackrel{f}{9}$ & $\stackrel{5}{0}$ & 8 & $\begin{array}{l}\tilde{O} \\
\dot{0}\end{array}$ & $\stackrel{\infty}{\infty}$ & $\overline{0}$ & $\stackrel{\infty}{0}$ & $\stackrel{8}{8}$ & $\stackrel{8}{8}$ & $\stackrel{8}{\circ}$ & $\stackrel{g}{:}$ & $\vec{b}$ & $\sigma_{0}$ & 帣 & $\begin{array}{c}\stackrel{4}{a} \\
\stackrel{n}{n}\end{array}$ & $\stackrel{\circ}{\infty}$ \\
\hline 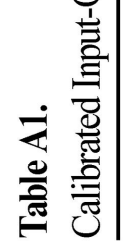 & 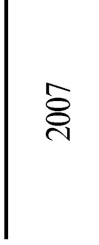 & 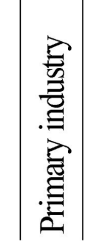 & 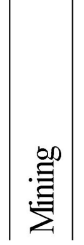 & 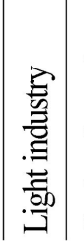 & 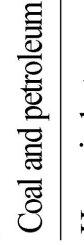 & 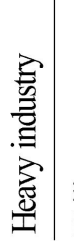 & 5 & 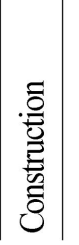 & $\frac{\mathscr{w}}{\tilde{w}}$ & 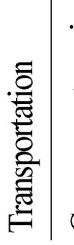 & 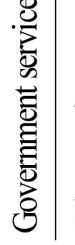 & 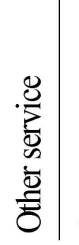 & & & | & & \\
\hline
\end{tabular}




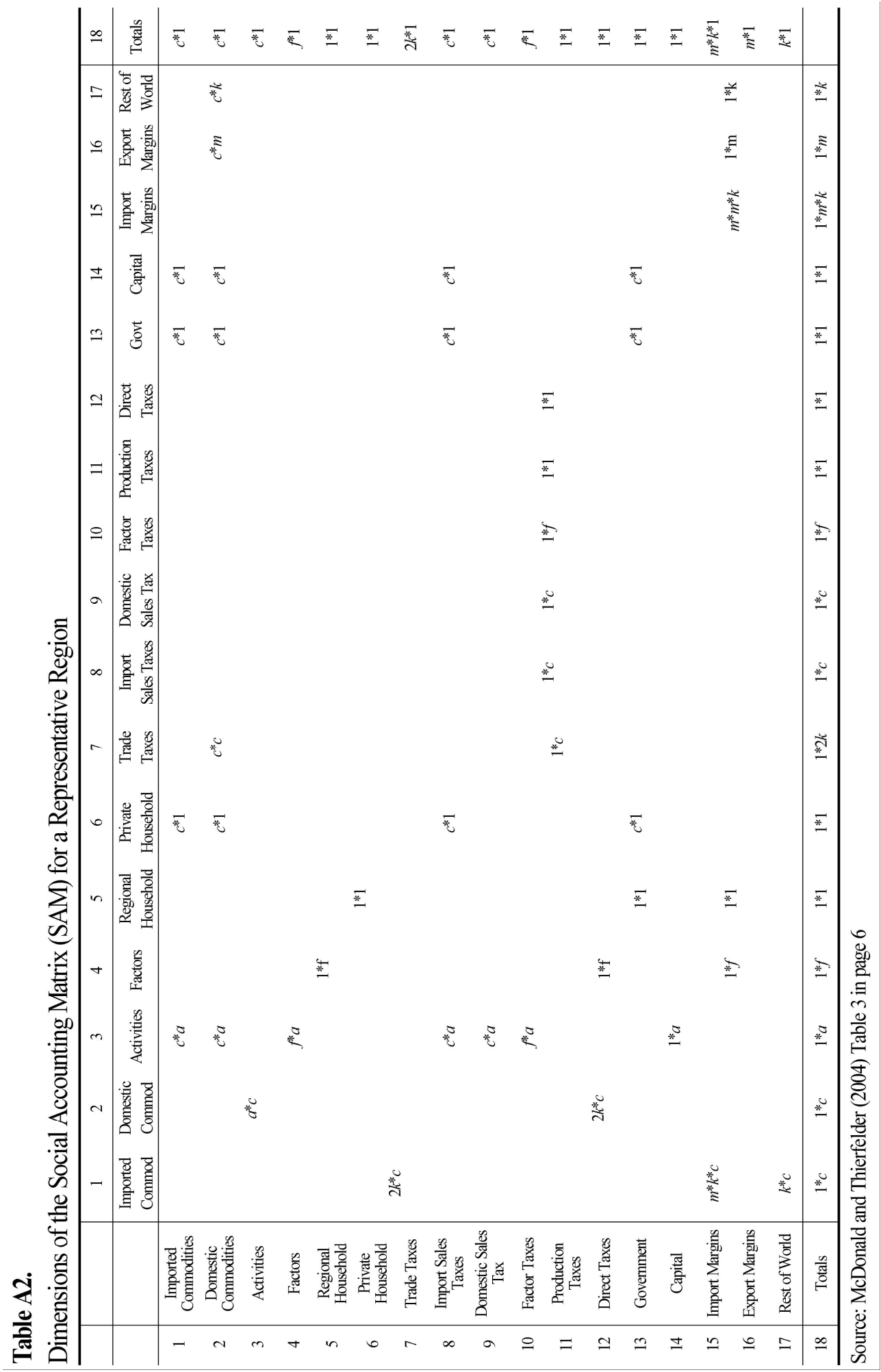




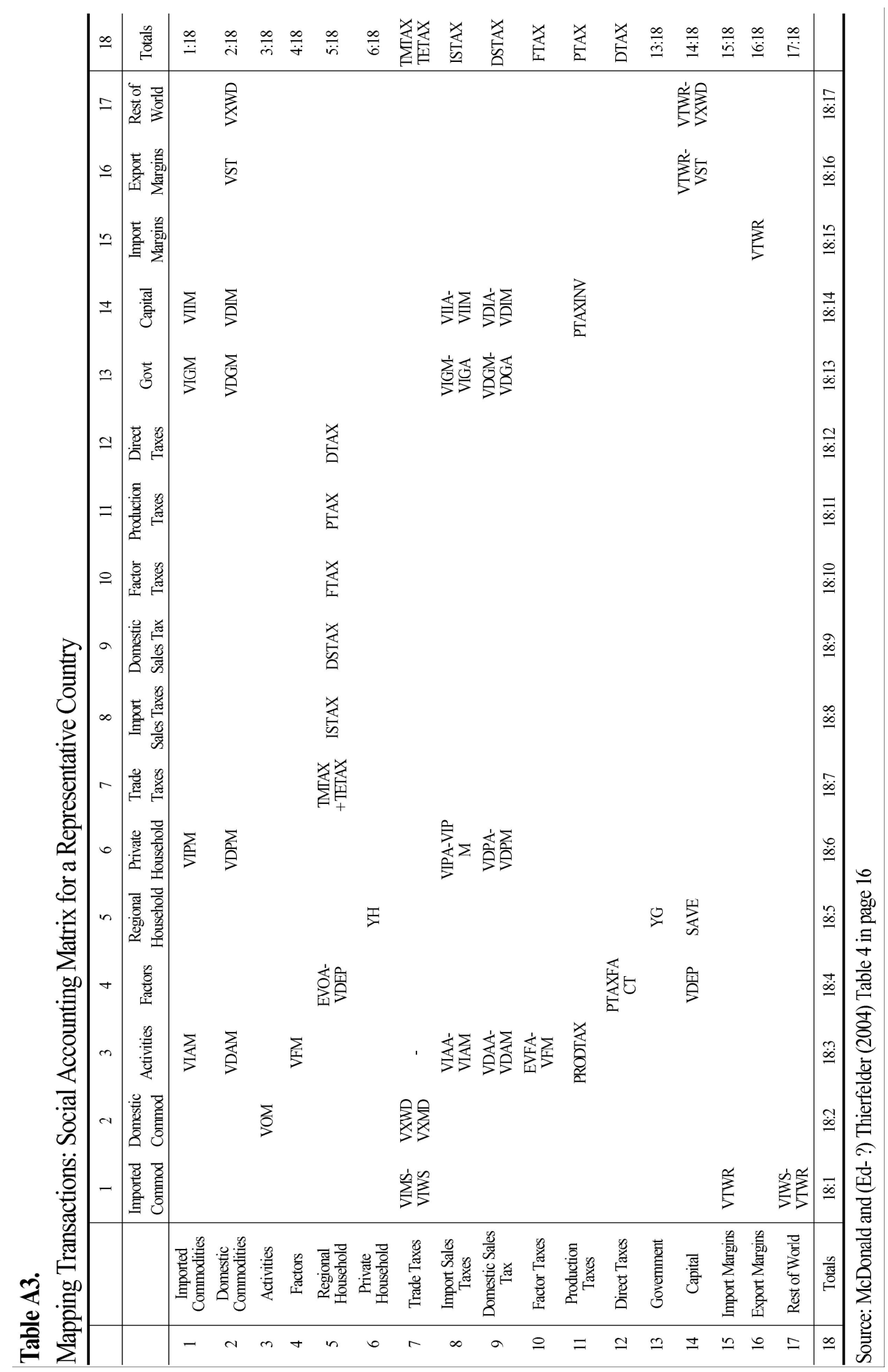

